Berkala Ilmu Perpustakaan dan Informasi, Vol. 14, No. 2, Desember 2018, Hal. 238-250 DOI: 10.22146/bip.36007

ISSN 1693-7740 (Print), ISSN 2477-0361 (Online)

Tersedia online di https://jurnal.ugm.ac.id/bip

\title{
Pemodelan personalisasi rekomendasi buku dengan pendekatan association rule mining
}

\author{
Sely Yoanda ${ }^{1}$, Imas Sukaesih Sitanggang ${ }^{2}$ dan Agus Buono ${ }^{2}$ \\ ${ }^{1}$ Program Studi Magister Teknologi Informasi untuk Perpustakaan, FMIPA, Institut Pertanian Bogor \\ ${ }^{2}$ Departemen Ilmu Komputer, FMIPA, Institut Pertanian Bogor \\ Email: selyoanda@gmail.com
}

Naskah diterima: 31 Mei 2018, direvisi: 6 Agustus 2018, disetujui: 12 September 2018

\begin{abstract}
ABSTRAK
Pendahuluan. Perpustakaan X adalah perpustakaan akademik di Jakarta, Indonesia. Perpustakaan X telah menyediakan Online Public Access Catalog (OPAC) sebagai sarana penelusuran informasi koleksi buku. Namun, terkadang informasi buku yang muncul tidak relevan sesuai kebutuhan pemustaka. Salah satu cara mengatasi masalah ini dengan sistem rekomendasi buku yang sesuai kebutuhan pemustaka. Tujuan penelitian ini untuk membuat model personalisasi rekomendasi buku pada Perpustakaan X.

Metode Penelitian. Metode dalam penelitian ini yakni association rule mining menggunakan algoritme Apriori. Hasil dan Pembahasan. Hasil menunjukkan bahwa hubungan aturan asosiasi buku untuk minimum support $0.1 \%$ dan minimum confidence $10 \%$ dan menghasilkan 42 aturan asosiasi. Dalam catatan bahwa 657 (Akuntansi) dan 658 (Manajemen) ditemukan dengan nilai support $2.6 \%$ dan confidence $14 \%$.

Kesimpulan dan Saran. Rekomendasi buku dirumuskan dengan memilih maximum support kemudian memilih maximum confidence. Sistem rekomendasi yang diusulkan terintegrasi dengan web dan e-mail pemustaka.
\end{abstract}

Kata Kunci: Algoritme Apriori; Association Rule Mining; Rekomendasi Buku; Data Transaksi Perpustakaan; Personalisasi

\section{ABSTRACT}

Introduction. Library X is an academic library in Jakarta, Indonesia. Library X has provided Online Public Access Catalog (OPAC) as a tool to provide information related to the collection. However, sometimes the information appears does not show high relevancy. One way to solve this problem is to develop user need basedbook recommendation system. The purpose of this study is to create personalization model of book recommendations in Library $X$.

Data Collection Method. The method used in this study was association rule mining using Apriori algorithm. Results and Discussions. The results showed that the book relationships for the minimum support was $0.1 \%$ and the minimum confidence was $10 \%$ and generated 42 association rules. It is noted that 657 (Accounting) and 658 (Management) are found to support for $2.6 \%$ with the confidence level for $14 \%$.

Conclusions. Book recommendation is formulated by selecting the rule with maximum support and confidence. The recommendation system is designed to be integrated to web application and user's e-mail.

Keywords: Apriori Algorithm; Association Rule Mining; Book Recommendation; Library Transaction Data; Personalization 


\section{A. PENDAhULUAN}

Perkembangan teknologi informasi telah meranah ke segala bidang termasuk perpustakaan. Perpustakaan sebagai lembaga informasi sudah seharusnya mengikuti perkembangan teknologi informasi guna memenuhi kebutuhan informasi pemustaka. Penelitian ini dilakukan di sebuah perpustakaan akademik di Jakarta dalam hal ini akan disebut dengan Perpustakaan X. Perpustakaan X menyediakan Online Public Access Catalog (OPAC) sebagai sarana penelusuran informasi koleksi buku. Namun, hal ini saja tidak cukup efisien karena kadang informasi buku yang muncul tidak relevan dengan kebutuhan pengguna dan membutuhkan waktu untuk menyeleksi kembali informasi buku yang ada sesuai dengan kebutuhannya.

Salah satu cara untuk memenuhi kebutuhan pemustaka mengenai informasi buku sesuai dengan kebutuhan dan karakteristik pemustaka yaitu sistem personalisasi rekomendasi buku. Banyak perpustakaan akademis telah mulai menyediakan layanan yang dipersonalisasi, seperti rekomendasi buku, untuk menarik pembaca menggunakan sumber perpustakaan (Xin, Haihong, Junde, Meina, \& Junjie, 2013). Tsuji, Takizawa, Sato, Ikeuchi, \& Ikeuchi (2014) menyebutkan bahwa untuk menghasilkan rekomendasi dengan merekomendasikan buku kepada pemustaka dapat dilakukan berdasarkan catatan transaksi peminjaman perpustakaan.

Wandi, Hendrawan, \& Mukhlason (2012) mengembangkan rekomendasi buku melalui web berdasarkan data sejarah peminjaman buku, kemudian melihat pola hubungan di antara buku-buku yang dipinjam pada tiap transaksi peminjaman dan tercatat pada sejarah peminjaman. Pola hubungan yang digunakannya dalam mendukung pengembangan sistem rekomendasi yakni menggunakan algoritme Apriori yang menghasilkan rekomendasi buku berdasarkan transaksi peminjaman buku yang ada. Li \& Chen (2008) juga melakukan penelitian yang sama menggunakan algoritme Apriori untuk menghasilkan hubungan antar buku. Sitanggang \& Agustina (2010) menerapkan sequential pattern mining menggunakan algoritme Apriori All pada dataset perpustakaan untuk membantu perpustakaan memberikan rekomendasi buku kepada pemustaka.

Latar belakang di atas menjadi acuan bagi penulis untuk merancang model personalisasi rekomendasi buku pada Perpustakaan X dengan pendekatan association rule mining menggunakan algoritme Apriori. Hasil yang diperoleh dari penelitian ini diharapkan dapat menjadi acuan dalam membuat sistem personalisasi rekomendasi buku. Penelitian ini bertujuan (1) menerapkan association rule mining pada data transaksi peminjaman buku di Perpustakaan X (2) merumuskan rekomendasi buku berdasarkan aturan asosiasi dari pendekatan association rule mining (3) merancang model personalisasi rekomendasi buku pada Perpustakaan X sesuai kebutuhan dan karakteristik pemustaka. Manfaat penelitian untuk memberikan informasi buku sesuai kebutuhan dan karakteristik pemustaka melalui perancangan model personalisasi rekomendasi buku. Penelitian ini memiliki keutamaan dalam pengembangan sistem di perpustakaan yang bertujuan untuk membantu pustakawan dalam berperan aktif merekomendasikan buku-buku yang dimilikinya kepada pemustaka secara personalisasi berdasarkan data pemustaka dan data sejarah peminjaman pemustaka. Kebaruan dalam penelitian ini adalah menyajikan framework sebagai model rancangan sistem personalisasi rekomendasi buku di perpustakaan yang sebelumnya hanya membahas terkait analisis aturan asosiasi yang diperoleh.

\section{B. TINJAUAN PUSTAKA Sistem Rekomendasi}

Menurut Masruri \& Mahmudy (2007), sistem rekomendasi menjadi salah satu bentuk sistem informasi personal yang digunakan dalam web e-commerce untuk menawarkan item dan memberi informasi yang dapat membantu pemustaka dalam memilih atau membeli item. Sistem rekomendasi membantu pemustaka untuk memilih objek yang mereka anggap berguna atau menarik minat mereka (Crespo et al., 2011). Di perpustakaan, sistem rekomendasi 
diterapkan untuk merekomendasikan buku. Xin et al., (2013) menyebutkan bahwa rekomendasi buku merupakan bagian penting dan tugas untuk layanan dan pendidikan personal yang diberikan oleh perpustakaan akademik. Tujuan dari sistem rekomendasi buku adalah untuk merekomendasikan buku yang sesuai dengan minat (Rajpurkar, Bhatt, \& Malhotra, 2015). Model layanan rekomendasi buku dapat menawarkan informasi buku kepada pembaca yang mungkin akan tertarik (Zhu \& Wang, 2007). Wandi et al. (2012) mengembangkan rekomendasi buku melalui web berdasarkan data sejarah peminjaman buku. Menurut Jomsri (2014), rekomendasi buku adalah proses untuk merekomendasikan buku bagi setiap pengguna dengan menggunakan hasil dari proses aturan asosiasi.

\section{Association Rule Mining}

Association rule mining menemukan hubungan yang menarik dan hubungan korelasi antar kumpulan data yang besar (Han, Kamber, \& Pei, 2012). Association rule memiliki korelasi antar item dengan bentuk $\mathrm{X} \cap \mathrm{Y}$, di mana $\mathrm{X}$ dan $\mathrm{Y}$ adalah disjoint itemsets, dinotasikan $\mathrm{X} \cap \mathrm{Y}=$ $\varnothing$ Kumpulan dari beberapa item atau lebih disebut dengan itemset, yang dinotasikan $I_{k}$ $(k=1,2, \ldots \mathrm{n})$. Jika itemset mempunyai item sebanyak k disebut $k$-itemset (Tan, Steinbach, \& Kumar, 2014).

Secara umum, association rule mining terdiri dari proses dua langkah yakni menemukan semua frequent itemset dan menghasilkan strong rule dari frequent itemset (Han et al., 2012). Strong rule yang dihasilkan ini harus memenuhi minimum support dan minimum confidence. Adapun ukuran support dan confidence (Han et al., 2012) dideskripsikan sebagai berikut:

Support adalah nilai perbandingan banyak transaksi suatu itemset terhadap jumlah transaksi pada dataset yang dinotasikan:

Support $(\mathrm{A} \rightarrow \mathrm{B})=\mathrm{P}(\mathrm{A} \mathrm{U} \mathrm{B})=\frac{\text { Jumlah transaksi mengandung A dan B }}{\text { Jumlah transaksi keseluruhan }}$
Confidence adalah tingkat kuatnya hubungan antar itemset dalam aturan asosiasi yang dinotasikan:

Confidence $(\mathrm{A} \rightarrow \mathrm{B})=\mathrm{P}(\mathrm{A} \mid \mathrm{B})=\frac{\text { Jumlah transaksi mengandung A dan } \mathrm{B}}{\text { Jumlah transaksi mengandung } \mathrm{A}}$

\section{Algoritme Apriori}

Apriori adalah algoritme yang diusulkan oleh R. Agrawal dan R. Srikant tahun 1994 untuk mining frequent itemsets. Apriori menggunakan pendekatan secara iterative yang disebut juga sebagai level-wise search, dimana $k$-itemset digunakan untuk mencari $(k+1)$ itemsets (Han et al., 2012). Prinsip algoritme ini, bila itemset digolongkan sebagai frequent itemset yang memiliki nilai support lebih dari yang ditetapkan sebelumnya, maka semua subsetnya juga termasuk golongan frequent itemset, dan sebaliknya (Li \& Chen, 2008). Penggunaan algoritme Apriori digunakan untuk membangkitkan frequent itemset yang memenuhi minimum support kemudian menghasilkan aturan yang memenuhi minimum confidence dari frequent itemset (Tan et al., 2014). Pseudo code algoritme Apriori dapat dilihat pada Gambar 1.

Gambar 1 menunjukkan bahwa algoritme Apriori dibagi menjadi beberapa tahap iterasi(perulangan) pada baris 1-11. Tiap iterasi membentuk pola dengan panjang item $k(k-$ itemset) dan di mulai dari banyak item 1 pada iterasi pertama. Iterasi akan membangkitkan kandidat $k$-itemsets baru menggunakan frequent $(k-1)$-itemsets yang ditemukan pada iterasi sebelumnya pada baris 3. Fungsi subset digunakan untuk menentukan semua kandidat itemsets dalam $\left(\mathrm{C}_{\mathrm{k}}\right)$ yang terkandung dalam setiap transaksi t pada baris 4. Untung menghitung support diimplementasikan pada baris 4-8. Itemset yang memiliki nilai support di bawah dari minimum support yang telah ditentukan pengguna akan dihapus. Langkah tersebut diulang sebanyak $k$ iterasi hingga semua frequent itemset yang ada diekstraksi. Algoritme akan berhenti ketika tidak ada lagi frequent itemset baru yang dihasilkan (Tan et al., 2014). Fungsi apriori gen merupakan fungsi pembentukan kandidat itemset $\left(\mathrm{C}_{\mathrm{k}}\right)$ yang melalui dua tahap yaitu join step dan prune step pada baris 12-19. 


\section{METODE PENELITIAN}

Penelitian ini dilakukan dengan pendekatan association rule mining menggunakan algoritme Apriori. Data yang digunakan yakni data transaksi peminjaman buku di Perpustakaan X tahun 2016-2017 yang dikelola dalam basis data aplikasi Senayan Library Information Management System (SLiMS) sebanyak 5.509 data transaksi peminjaman buku. Tahapan penelitian pada Gambar 2.

Penelitian dimulai dengan mengidentifikasi masalah penggunaan OPAC. Kemudian, melakukan pengumpulan data dan dilanjutkan praproses data melalui proses memilih data yang relevan dan membuat dataset transaksi peminjaman buku. Data relevan yang digunakan dibatasi pada nomor klasifikasi DDC ringkasan ketiga. Hasil dari praproses data digunakan pada penerapan algoritme Apriori. Penerapan algoritme Apriori bertujuan untuk menentukan pola peminjaman buku menggunakan tools Waikato Environment for Knowledge Analysis (WEKA) yang dilakukan dengan cara menentukan nilai minimum support dan minimum confidence.

Tahap selanjutnya melakukan penyusunan rekomendasi buku berdasarkan aturan asosiasi yang telah dihasilkan dari penerapan algoritme Apriori. Menurut Jomsri (2014) cara merekomendasikan buku menggunakan association rule mining adalah (1) memilih aturan dengan maximum confidence (2) memilih aturan dengan maximum support jika nilai confidence adalah sama (3) memilih aturan yang terjadi pertama kali ketika nilai confidence dan support adalah sama. Tahap akhir adalah merancang model personalisasi rekomendasi buku. Rancangan model yang akan dibuat berdasarkan penyusunan rekomendasi buku yang telah diperoleh dari hasil aturan asosiasi. Hasil dari rancangan model akan menjadi acuan pembuatan sistem rekomendasi buku termasuk informasi buku baru yang akan direkomendasikan melalui e-mail dan web. Framework sistem rekomendasi buku dapat dilihat pada Gambar 3.

Mekanisme framework sistem rekomendasi buku dirancang dalam tiga tahap yaitu (1) data sejarah setiap transaksi peminjaman pengguna dikumpulkan setelah proses peminjaman oleh pengguna (2) mempersiapkan dan memilih data yang relevan untuk membuat model aturan asosiasi (3) merekomendasikan buku kepada setiap pemustaka menggunakan hasil dari proses aturan asosiasi.

\section{HASIL DAN PEMBAHASAN Tampilan User Interface}

Data yang dipilih dalam penelitian ini meliputi id transaksi, tanggal peminjaman, id anggota, dan barcode. Contoh data transaksi peminjaman buku yang diperoleh dari aplikasi SLiMS dapat dilihat pada Tabel 1.

Praproses Data Transaksi Peminjaman Buku Pada tahap praproses data, dataset dibuat berdasarkan id anggota, tanggal peminjaman, dan nomor klasifikasi dan diperoleh sebanyak 3.435 transaksi dengan kriteria yakni pada tanggal dan id anggota yang sama, pemustaka meminjam buku dengan nomor klasifikasi apa saja. Daftar item buku yang berhasil ditemukan dilihat pada Tabel 2.

Proses untuk mengolah data transaksi peminjaman buku menggunakan WEKA dilakukan pengubahan data ke dalam bentuk file .CSV. Proses transformasi ini adalah jika item yang dipinjam maka akan diganti dengan huruf ("t") yang bernilai true. Sedangkan, item yang tidak dipinjam maka akan diganti dengan tanda tanya ("?") yang bernilai no. Berikut dataset transaksi peminjaman buku dalam bentuk CSV pada Tabel 3 .

\section{Penerapan Algoritme Apriori}

Proses penerapan algoritme Apriori menggunakan tools WEKA dan dengan data transaksi peminjaman buku yang telah diubah kedalam bentuk file CSV. Hasil input dataset transaksi peminjaman buku tahun 2016-2017 diketahui berjumlah 3.345 transaksi dengan item sebanyak 71. Langkah selanjutnya dilakukan pengolahan data. Agar hasil pengolahan data muncul maka perlu dilakukan pengaturan nilai minimum support dan minimum confidence. Tidak ada batasan dalam menentukan nilai minimum support dan minimum confidence, nilai ini diberikan hingga 
aturan asosiasi yang dibutuhkan muncul sesuai dengan kebutuhan dalam penelitian. Pada penelitian ini nilai minimum support yang diberikan yakni $10 \%, 2 \%, 1 \%$, dan $0.1 \%$. Sedangkan nilai minimum confidence yang diberikan yakni 10, 20, 30, 40, dan 50\%. Setelah menginput nilai minimum support dan minimum confidence yang telah ditentukan. maka akan muncul hasil pengolahan WEKA yang dapat dilihat pada Gambar 4.

Untuk setiap aturan asosiasi yang telah dihasilkan, nomor pertama di antara tanda kurung melambangkan nilai support, yang kedua adalah nilai confidence. Aturan asosiasi pertama adalah aturan yang memiliki nilai support $0.08 \%$ dan nilai confidence $100 \%$. Hal ini berarti bahwa $0.08 \%$ dari transaksi mengandung peminjaman dengan kode buku C001 (Ilmu Pengetahuan), C153 (Intelegensia, Kecerdasan Proses Intelektual dan Mental, dan C302 (Interaksi Sosial, Hubungan Antarpersonal). Sedangkan, nilai confidence sebesar $100 \%$ mempunyai arti bahwa tingkat kepastian pemustaka meminjam buku dengan kode buku C001 (Ilmu Pengetahuan) dan C153 (Intelegensia, Kecerdasan Proses Intelektual dan Mental bersamaan dengan C302 (Interaksi Sosial, Hubungan Antarpersonal) bernilai 100\%. Berdasarkan hasil pengolahan WEKA terdapat frequent itemset yang dibangkitkan pada nilai minsup yang ditetapkan. Jumlah frequent itemset yang dibangkitkan pada minsup yang telah ditentukan dapat dilihat pada Tabel 4.

Tabel 4 menunjukkan bahwa jumlah frequent itemset terbanyak dibangkitkan oleh minsup $0.1 \%$, sedangkan frequent itemset paling sedikit dibangkitkan oleh minsup 10\%. Nilai minimum support digunakan untuk menemukan $l$-large itemsets, $l=1,2,3$. Dalam penelitian ini nilai minimum support yang digunakan adalah $10 \%, 2 \%, 1 \%$, dan $0.1 \%$. Untuk minimum support $10 \%$ tidak ditemukan l-large itemsets. Untuk minimum support 2\% ditemukan 14 frequent itemset yang terdiri dari 1-large itemsets yang disingkat L(1) sebanyak 12 dan 2large itemsets yang disingkat L(2) sebanyak 2 . L(1) pada minsup 2\% adalah C346, C338, C004, C330, C659, C336, C001, C302, C332, C650, C657, C658. Sedangkan L(2) pada minsup 2\% adalah C650 C658, C657 C658. Selain itu, hasil pengolahan WEKA juga menghasilkan aturan asosiasi. Adapun jumlah aturan asosiasi yang dihasilkan berdasarkan nilai minimum support dan minimum confidence dapat dilihat pada Tabel 5 .

Tabel 5 menunjukkan jumlah aturan asosiasi yang dihasilkan dari masing-masing nilai minimum support dan minimum confidence yang diberikan. Berdasarkan tabel 5 dapat disimpulkan bahwa semakin kecil nilai support dan confidence yang diberikan, maka aturan asosiasi yang dihasilkan akan semakin banyak.

\section{Proses Penyusunan Rekomendasi Buku Berdasarkan Aturan Asosiasi}

Setelah melakukan percobaan beberapa parameter, maka diambil minimum support $0.1 \%$ dan minimum confidence $10 \%$ yang menghasilkan sebanyak 42 aturan asosiasi untuk dilakukan penyusunan rekomendasi buku. Adapun aturan yang dihasilkan berdasarkan pada nilai minimum support dan minimum confidence yang telah ditetapkan dapat dilihat pada Tabel 6 .

Aturan asosiasi yang telah dihasilkan dalam penelitian ini disesuaikan dengan tiga cara Jomsri (2014) dalam merekomendasikan buku menggunakan association rule mining. Pertama, memilih aturan dengan maximum confidence yang terdapat pada aturan ke 42 dengan nilai confidence 1 . Namun pada aturan ke 42 dalam Penelitian ini, nilai support sangat kecil dibandingkan aturan yang ada untuk direkomendasikan kepada pemustaka yakni hanya 3 kali transaksi yang meminjam kode buku C001 dan C153 yang kemudian terjadi pula 3 kali transaksi saja yang meminjam kode buku C001, C153, dan C302. Kedua, memilih aturan dengan maximum support jika nilai confidence sama. Adapun nilai maximum support terdapat pada aturan ke 1 dan 2 yang keduanya tidak memiliki nilai confidence yang sama. Ketiga, memilih aturan yang terjadi pertama kali ketika nilai confidence dan support adalah sama yakni terdapat pada aturan ke 23 dan 24.

Setelah melakukan evaluasi tentang penyusunan rekomendasi buku menggunakan 
ketentuan yang dinyatakan oleh Jomsri (2014), maka dihasilkan perumusan dalam proses rekomendasi buku dalam penelitian ini yaitu dengan memilih maximum support kemudian memilih maximum confidence. Sebagai contoh pada aturan nomor 5 dan 6 yang memiliki nilai support sama, maka yang terlebih dahulu direkomendasikan yakni aturan no 6 karena nilai confidence lebih tinggi.

\section{Perancangan Model Personalisasi Rekomendasi Buku}

Rancangan model akan bekerja sesuai dengan framework sistem rekomendasi buku. Usulan framework sistem rekomendasi buku Perpustakaan X diberikan pada Gambar 5. Sistem rekomendasi buku ini diintegrasikan dengan aplikasi web melalui OPAC sebagai layanan penelusuran informasi buku dan melalui basis data pemustaka layanan buku dengan data yang digunakan yakni data pemustaka dan data sejarah peminjaman buku. Sistem rekomendasi buku berdasarkan pendekatan association rule mining akan menampilkan rekomendasi buku melalui web dan e-mail pemustaka. Gambar 6 menyajikan tampilan rekomendasi buku melalui web.

Gambar 6 menunjukkan tampilan rekomendasi buku melalui web yang akan tampil ketika pemustaka melakukan penelusuran informasi buku yang diinginkan. Rekomendasi buku secara otomatis diberikan oleh sistem berdasarkan association rule mining dengan memilih nilai maximum support kemudian maximum confidence dan berdasarkan data pemustaka.

\section{E. KESIMPULAN}

Hasil penerapan association rule mining menggunakan algoritme Apriori pada data transaksi peminjaman buku di Perpustakaan X membangkitkan 99 jumlah frequent itemset dan menghasilkan 42 aturan asosiasi dengan minimum support dan minimum confidence sebesar $0.1 \%$ dan $10 \%$. Aturan asosiasi yang sering dipinjam oleh pengguna yaitu hubungan antara kode buku C657 (Akuntansi) sebanyak 651 transaksi bersamaan dengan kode buku C658 (Manajemen Umum) sebanyak 90 transaksi dengan nilai support sebesar $2.6 \%$ dan nilai confidence sebesar $14 \%$. Perumusan rekomendasi buku dilakukan dengan memilih maximum support kemudian memilih maximum confidence. Berdasarkan proses yang telah dilakukan dirancanglah sebuah model personalisasi rekomendasi buku yang akan tampil pada halaman web dan e-mail pemustaka.

Saran yang diberikan pada penelitian yakni penelitian selanjutnya dapat lebih diperluas batasan nomor klasifikasi yang digunakan agar buku yang direkomendasikan kepada pemustaka dapat menjadi lebih spesifik. Perpustakaan X dapat mengimplementasikan rancangan sistem rekomendasi buku melalui web penelusuran buku dan e-mail pemustaka.

\section{DAFTAR PUSTAKA}

Agrawal, R., \& Srikant, R. (1994). Fast algorithms for mining association rules. In Proceedings of the 20th VLDB Conference (pp. 487-499). Santiago: Institute of Electrical and Electronics Engineers. https://doi.org/10.1007/BF02948845

Crespo, R. G., Martínez, O. S., Lovelle, J. M. C., García-Bustelo, B. C. P., Gayo, J. E. L., \& Pablos, P. O. De. (2011). Recommendation system based on user interaction data applied to intelligent electronic books. Computers in Human Behavior, 27(4), 1445-1449. https://doi.org/10.1016/ j.chb.2010.09.012

Han, J., Kamber, M., \& Pei, J. (2012). Data mining: concepts and techiques (3rd ed.). Waltham: Morgan Kaufman.

Jomsri, P. (2014). Book recommendation system for digital library based on user profiles by using association rule. In Innovative Computing Technology (pp. 130-134). Luton: Institute of Electrical and Electronics Engineers. https://doi.org/ 10.1109/INTECH.2014.6927766 
Li, J., \& Chen, P. (2008). The application of association rule in library system. In International Symposium on Knowledge Acquisition and Modeling Workshop Proceedings (pp. 248-251). Wuhan, China: Institute of Electrical and Electronics Engineers. https://doi.org/10.1109/ KAMW.2008.4810472

Masruri, F., \& Mahmudy, W. F. (2007). Personalisasi web e-commerce menggunakan recommender system dengan metode item-based collaborative filtering. Kursor, 3(1), 1-12. Retrieved Mei 14, 2017, from http://wayanfm.lecture.ub.ac.id/ files/2014/03/200701-Kursor-FaridWayan-Recommender-System.pdf

Rajpurkar, S., Bhatt, D., \& Malhotra, P. (2015). B ook recommendation system. International for Innovative Research in Science and Technology, 1(11), 314-316. Retrieved Mei 14, 2017 , from w w w. i j i r t.org/articles/ IJIRSTV1I11135.pdf

Sitanggang, I. S., Husin, N. A., Agustina, A., \& Mahmoodian, N. (2010). Sequential pattern mining on library transaction data. In International Symposium on Information Technology (pp. 1-4). Kuala Lumpur, Malaysia: Institute of Electrical and Electronics Engineers. https://doi.org/ 10.1109/ITSIM.2010.5561316

Tan, P.-N., Steinbach, M., \& Kumar, V. (2014). Introduction to data mining (1st ed.). Harlow: Pearson Education Limited.
Tsuji, K., Takizawa, N., Sato, S., Ikeuchi, U., Ikeuchi, A., Yoshikane, F., \& Itsumura, H. (2014). Book recommendation based on library loan records and bibliographic information. Procedia-Social and Behavioral Sciences, 147, 478-486. https://doi.org/10.1109/IIAI-AAI.2014.26

Wandi, N., Hendrawan, R. A., \& Mukhlason, A. (2012). Pengembangan sistem rekomendasi penelusuran buku dengan penggalian association rule menggunakan algoritma apriori (studi kasus Badan Perpustakaan dan Kearsipan Provinsi Jawa Timur). Jurnal Teknik ITS, 1(1), 1-5. https//doi.org/ 10.12962/j23373539.v1i1.1293

Xin, L., Haihong, E., Junde, S., Meina, S., \& Junjie, T. (2013). Collaborative book recommendation based on readers' borrowing records. In International Conference on Advanced Cloud and Big Data (pp. 159-163). Nanjing, China: Institute of Electrical and Electronics Engineers. https://doi.org/10.1109/ CBD.2013.14

Zhu, Z., \& Wang, J.-Y. (2007). Book recommendation service by improved association rule mining algorithm. In Proceedings of the Sixth International Conference on Machine Learning and Cybernetics (pp. 3864-3869). Hong Kong, China: Institute of Electrical and Electronis Engineers. https://doi.org/10.1109/ ICMLC.2007.4370820 


\section{DAFTAR GAMBAR}

$\mathrm{C}_{\mathrm{k}}$ : Candidate itemset of size $\mathrm{k} \mid \mathrm{L}_{\mathrm{k}}$ : frequent itemset of size $\mathrm{k}$

1. $L_{1}=\{$ large 1 -itemset $\}$;

2. for $\left(\mathrm{k}=2 ; \quad L_{\mathrm{k}-1} \neq \varnothing ; \mathrm{k}++\right)$ do begin

3. $\quad C_{\mathrm{k}}=$ apriori-gen $\left(L_{\mathrm{k}-1}\right) ; / /$ New candidates

4. forall transactions $t \in D$ do begin

5. $\quad C_{1}=\operatorname{subset}\left(\mathrm{C}_{k}, t\right) ; / /$ Candidates contained in $t$

6. forall candidates $c \in C_{1}$ do

$7 . \quad$ c.count ++ ;

8. $\quad$ end

9. $\quad L_{\mathrm{k}}=\left\{c \in C_{\mathrm{t}} \mid c\right.$. count $\left.\geq \operatorname{minsup}\right\}$

10 . end

11. Answer $=\mathrm{U}_{\mathrm{k}} L_{\mathrm{k}}$;

// Join step

12. insert into $C_{\mathrm{k}}$

13. select $p \cdot$ item $_{1}, p \cdot$ item $_{2}, \ldots, p \cdot$ item $_{k-1}, q \cdot$ item $_{k-1}$

14. from $L_{\mathrm{k}-1} p, L_{\mathrm{k}-1} q$

15. where $p \cdot$ item $_{1}=q \cdot$ item $_{1}, \ldots, p \cdot$ item $_{k-2}=q \cdot$ item $_{k-2}$,

// Prune step

$$
p \cdot \text { item }_{k-1}<q . \text { item }_{k-1} \text {; }
$$

16. for each itemsets $\mathrm{c} \in C_{\mathrm{t}}$ do

17. for each $(\mathrm{k}-1)$ - subsets $\mathrm{s}$ of $\mathrm{c}$ do

18. if $(s-r)$ then

Gambar 1. Pseudocode Algoritme Apriori (Agrawal \& Srikant, 1994)

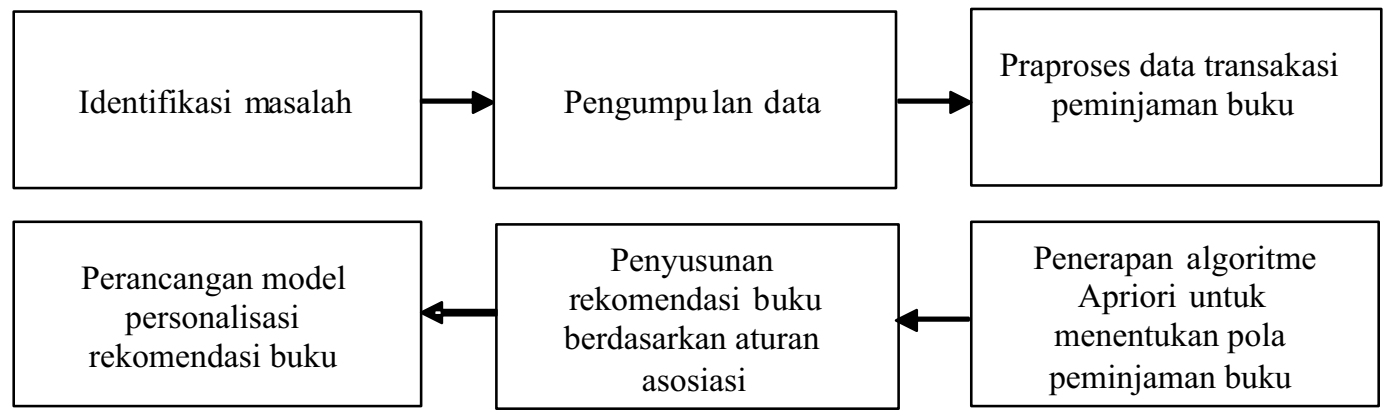

Gambar 2. Tahapan penelitian 


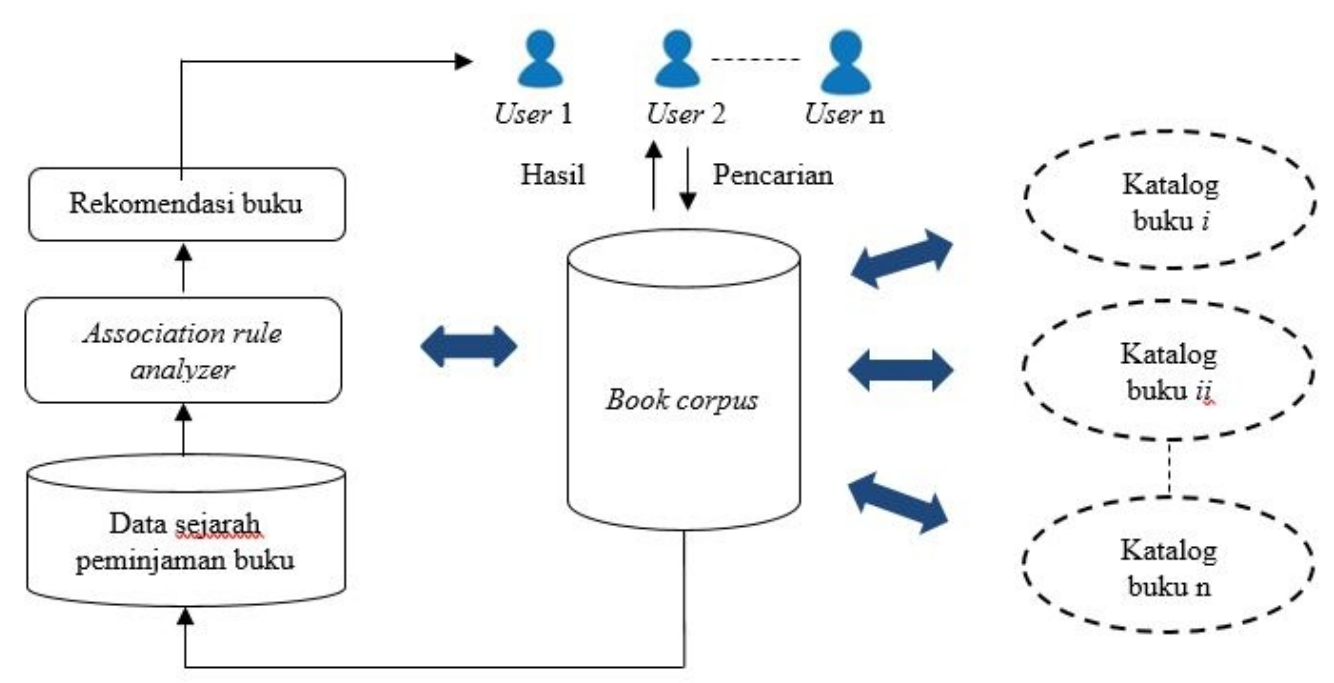

Gambar 3. Framework sistem rekomendasi buku (Jomsri, 2014)

Generated sets of large itemsets:

Size of set of large itemsets L(1): 43

Size of set of large itemsets L(2): 48

Size of set of large itemsets L(3): 8

Best rules found:

1. $\mathrm{C} 001=\mathrm{t} \mathrm{C} 153=\mathrm{t} 3=\mathrm{C} 302=\mathrm{t} 3 \quad(0.08 \%, 100 \%)$

2. $\mathrm{C} 101=\mathrm{t} \mathrm{C} 302=\mathrm{t} 6==\mathrm{C} 153=\mathrm{t} 5 \quad(0.14 \%, 83 \%)$

3. $\mathrm{C} 101=\mathrm{t} \mathrm{C} 153=\mathrm{t} 6=\mathrm{C} 302=\mathrm{t} 5 \quad(0.14 \%, 83 \%)$

4. $\mathrm{C} 338=\mathrm{t} \mathrm{C} 650=\mathrm{t} 8==>\mathrm{C} 330=\mathrm{t} 4 \quad(0.11 \%, 50 \%)$

Gambar 4. Hasil pengolahan menggunakan WEKA 


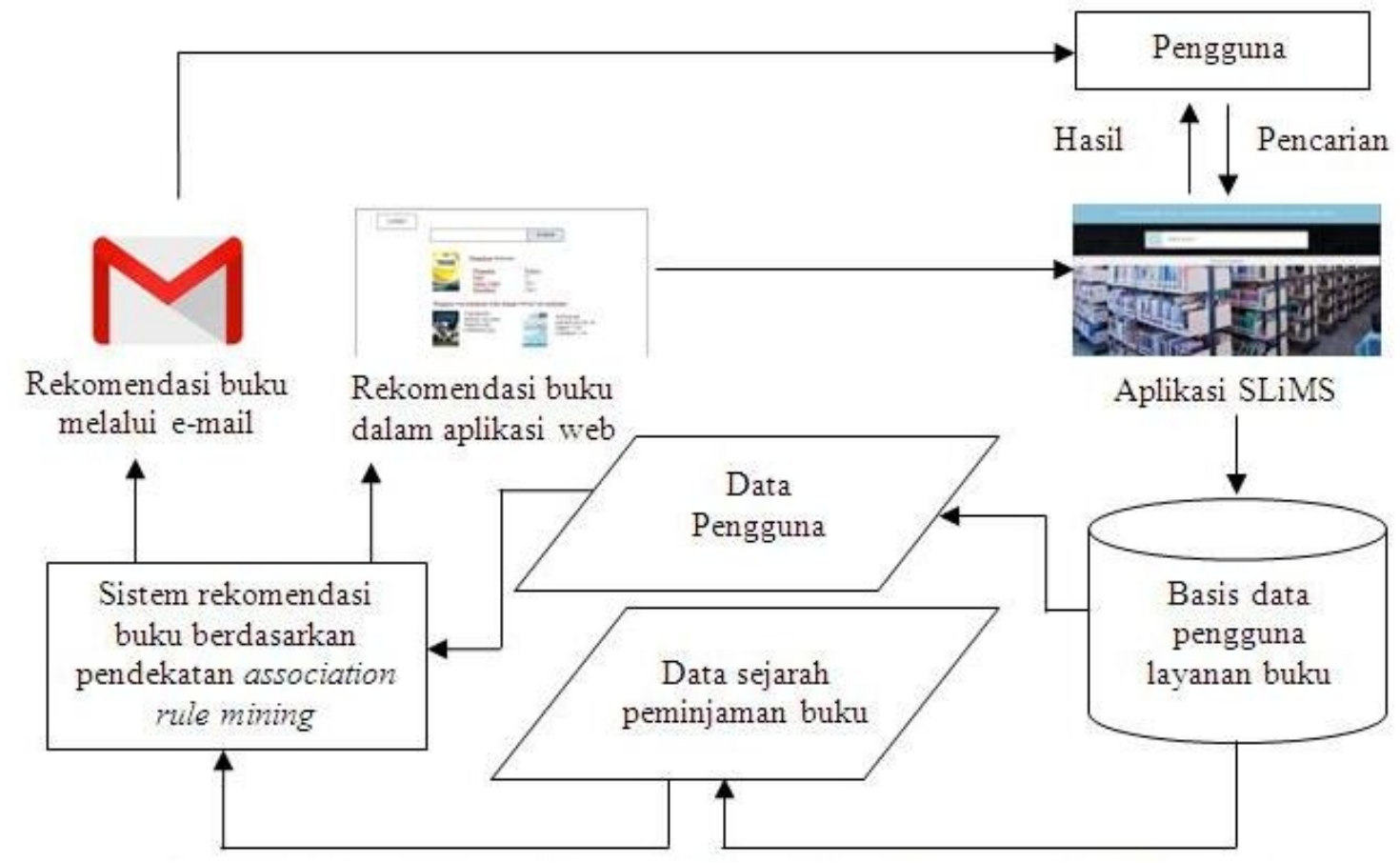

Gambar 5. Framework sistem rekomendasi buku Perpustakaan X

\section{LOGO}

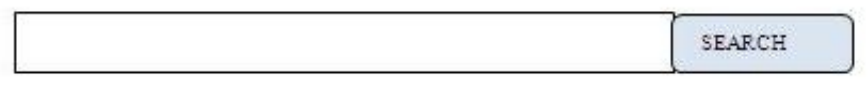

\begin{tabular}{|c|c|c|}
\hline$=$ & jjakan & es \\
\hline 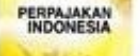 & Pengarang & Waluyc \\
\hline & Edisi & $: \quad 12$ \\
\hline 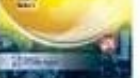 & $\begin{array}{l}\text { Tahun Terbit } \\
\text { Klasifikasi }\end{array}$ & $\begin{array}{ll}: \quad 2017 \\
: \quad 336.2\end{array}$ \\
\hline
\end{tabular}

Perpajakan: teori dan kasus

$\begin{array}{lll}\text { Perpaakan } & \text { Pengarang } & : \text { Resmi, Siti } \\ \text { Edisi } & : & 7 \\ \text { Tahun Terbit } & : & 2012 \\ \text { Klasifikasi } & : 336.2\end{array}$

Pengguna yang meminjam buku dengan item ini juga meminjam

Kode buku C657

Support: 0.005

Confidence: 0.16

Gambar 6. Rancangan rekomendasi buku pada tampilan web 


\section{DAFTAR TABEL}

Tabel 1. Perangkat lunak institutional repository dan jumlah penggunanya

\begin{tabular}{|c|c|c|c|}
\hline Id transaksi & Tanggal p eminjaman & Id anggota & Barcode \\
\hline 15903 & 14-Nov-17 & 29140153 & S1.04.0242 \\
\hline 15904 & 14-Nov-17 & 29140153 & MN.02.16.032 \\
\hline 15905 & 15-Nov-17 & 28140231 & TI.10.16.001 \\
\hline 15906 & 15-Nov-17 & 28140231 & SI.10.12.007 \\
\hline 15907 & 15-Nov-17 & 28140231 & S1.06.0588 \\
\hline 15908 & 21-Nov-17 & 62130107 & IK.07.15.013 \\
\hline 15909 & 21-Nov-17 & 62130107 & AB.10.12.007 \\
\hline 15910 & 22-Nov-17 & 751601004 & S1L.01.09113 \\
\hline 15911 & 23-Nov-17 & 62140192 & IK.09.16.008 \\
\hline 15912 & 24-Nov-17 & 39120153 & AK.10.10.016 \\
\hline 15913 & 24-Nov-17 & 39120153 & S1L.01.10450 \\
\hline 15914 & 25-Nov-17 & 771701008 & S1.07.0016 \\
\hline
\end{tabular}

Sumber: Data penelitian 2017

Tabel 2. Perangkat Lunak yang digunakan

\begin{tabular}{|c|c|c|}
\hline Id anggota & Item & Nomor klasifikasi \\
\hline 29140153 & 332,658 & $\begin{array}{l}332 \text { = Ekonomi Keuangan dan Finansial, Ekonomi Biaya dan } \\
\text { Pembiayaan, } 658 \text { = Manajemen Umum }\end{array}$ \\
\hline 28140231 & $005,650,658$ & $005=$ Pemrograman, $650=$ Bisnis, $658=$ Manajemen \\
\hline 62130107 & 302,650 & $302=$ Interaksi Sosial, Hubungan Antarpersonal, $650=$ Bisnis \\
\hline 0751601004 & 658 & $658=$ Manajemen Umum \\
\hline 62140192 & 808 & $808=$ Retorik, Retorika dan Kumpulan Karya Sastra \\
\hline 39120153 & 336,657 & $336=$ Keuangan Negara, $657=$ Akuntansi \\
\hline 07701701008 & 658 & $658=$ Manajemen Umum \\
\hline
\end{tabular}

Sumber: Data penelitian 2017 
Tabel 3. Dataset transaksi peminjaman buku dalam bentuk CSV

\begin{tabular}{cccccccc}
\hline $\mathbf{0 0 5}$ & $\mathbf{3 0 2}$ & $\mathbf{3 3 2}$ & $\mathbf{3 3 6}$ & $\mathbf{6 5 0}$ & $\mathbf{6 5 7}$ & $\mathbf{6 5 8}$ & $\mathbf{8 0 8}$ \\
\hline$?$ & $?$ & $\mathrm{t}$ & $?$ & $?$ & $?$ & $\mathrm{t}$ & $?$ \\
$\mathrm{t}$ & $?$ & $?$ & $?$ & $\mathrm{t}$ & $?$ & $\mathrm{t}$ & $?$ \\
$?$ & $\mathrm{t}$ & $?$ & $?$ & $\mathrm{t}$ & $?$ & $?$ & $?$ \\
$?$ & $?$ & $?$ & $?$ & $?$ & $?$ & $\mathrm{t}$ & $?$ \\
$?$ & $?$ & $?$ & $?$ & $?$ & $?$ & $?$ & $\mathrm{t}$ \\
$?$ & $?$ & $?$ & $\mathrm{t}$ & $?$ & $\mathrm{t}$ & $?$ & $?$ \\
$?$ & $?$ & $?$ & $?$ & $?$ & $?$ & $\mathrm{t}$ & $?$ \\
\hline
\end{tabular}

Sumber: Data penelitian 2017

Tabel 4. Jumlah frequent itemset

\begin{tabular}{cc}
\hline Minimum support & Jumlah frequent itemset \\
\hline $10 \%$ & Tidak diperoleh frequent itemset \\
$2 \%$ & 14 \\
$1 \%$ & 19 \\
$0.1 \%$ & 99 \\
\hline
\end{tabular}

Sumber: Data penelitian 2017

Tabel 5. Jumlah aturan asosiasi

\begin{tabular}{ccccc}
\hline \multirow{2}{*}{ Minimum confidence } & \multicolumn{4}{c}{ Minimum support } \\
& $\mathbf{0 . 1 \%}$ & $\mathbf{1 \%}$ & $\mathbf{2 \%}$ & $\mathbf{1 0 \%}$ \\
\hline $10 \%$ & 42 & 3 & 2 & - \\
$20 \%$ & 28 & 2 & 1 & - \\
$30 \%$ & 19 & 1 & 1 & - \\
$40 \%$ & 8 & - & - & - \\
$50 \%$ & 6 & - & - & - \\
\hline
\end{tabular}

Sumber: Data penelitian 2017 
Tabel 6. Aturan Asosiasi

\begin{tabular}{|c|c|c|c|c|c|c|c|c|}
\hline \multirow{2}{*}{$\begin{array}{c}\text { No } \\
1\end{array}$} & \multicolumn{6}{|c|}{ Aturan asosiasi } & \multirow{2}{*}{$\frac{\text { Support relative }}{0.026200873}$} & \multirow{2}{*}{$\begin{array}{c}\text { confidence } \\
0.14\end{array}$} \\
\hline & $\mathrm{C} 657=\mathrm{t}$ & & 651 & $\mathrm{C} 658=\mathrm{t}$ & & 90 & & \\
\hline 2 & $\mathrm{C} 650=\mathrm{t}$ & & 208 & $\mathrm{C} 658=\mathrm{t}$ & & 70 & 0.020378457 & 0.34 \\
\hline 3 & $\mathrm{C} 332=\mathrm{t}$ & & 188 & $\mathrm{C} 658=\mathrm{t}$ & & 43 & 0.012518195 & 0.23 \\
\hline 4 & $\mathrm{C} 650=\mathrm{t}$ & & 208 & $\mathrm{C} 657=\mathrm{t}$ & & 25 & 0.00727802 & 0.12 \\
\hline 5 & $\mathrm{C} 336=\mathrm{t}$ & & 125 & $\mathrm{C} 657=\mathrm{t}$ & & 20 & 0.005822416 & 0.16 \\
\hline 6 & $\mathrm{C} 338=\mathrm{t}$ & & 91 & $\mathrm{C} 658=\mathrm{t}$ & & 20 & 0.005822416 & 0.22 \\
\hline 7 & $\mathrm{C} 659=\mathrm{t}$ & & 106 & $\mathrm{C} 658=\mathrm{t}$ & & 19 & 0.005531295 & 0.18 \\
\hline 8 & $\mathrm{C} 302=\mathrm{t}$ & & 139 & $\mathrm{C} 153=\mathrm{t}$ & & 14 & 0.004075691 & 0.1 \\
\hline 9 & $\mathrm{C} 153=\mathrm{t}$ & & 40 & $\mathrm{C} 302=\mathrm{t}$ & & 14 & 0.004075691 & 0.35 \\
\hline 10 & $\mathrm{C} 001=\mathrm{t}$ & & 125 & $\mathrm{C} 658=\mathrm{t}$ & & 13 & 0.003784571 & 0.1 \\
\hline 11 & $\mathrm{C} 330=\mathrm{t}$ & & 104 & $\mathrm{C} 650=\mathrm{t}$ & & 12 & 0.00349345 & 0.12 \\
\hline 12 & $\mathrm{C} 330=\mathrm{t}$ & & 104 & $\mathrm{C} 657=\mathrm{t}$ & & 12 & 0.00349345 & 0.12 \\
\hline 13 & $\mathrm{C} 005=\mathrm{t}$ & & 67 & $\mathrm{C} 658=\mathrm{t}$ & & 12 & 0.00349345 & 0.18 \\
\hline 14 & $\mathrm{C} 174=\mathrm{t}$ & & 33 & $\mathrm{C} 658=\mathrm{t}$ & & 8 & 0.002328967 & 0.24 \\
\hline 15 & $\mathrm{C} 303=\mathrm{t}$ & & 30 & $\mathrm{C} 302=\mathrm{t}$ & & 7 & 0.002037846 & 0.23 \\
\hline 16 & $\mathrm{C} 153=\mathrm{t}$ & & 40 & $\mathrm{C} 101=\mathrm{t}$ & & 6 & 0.001746725 & 0.15 \\
\hline 17 & $\mathrm{C} 101=\mathrm{t}$ & & 15 & $\mathrm{C} 153=\mathrm{t}$ & & 6 & 0.001746725 & 0.4 \\
\hline 18 & $\mathrm{C} 101=\mathrm{t}$ & & 15 & $\mathrm{C} 302=\mathrm{t}$ & & 6 & 0.001746725 & 0.4 \\
\hline 19 & $\mathrm{C} 153=\mathrm{t}$ & & 40 & $\mathrm{C} 101=\mathrm{t}$ & $\mathrm{C} 302=\mathrm{t}$ & 5 & 0.001455604 & 0.13 \\
\hline 20 & $\mathrm{C} 650=\mathrm{t}$ & $\mathrm{C} 657=\mathrm{t}$ & 25 & $\mathrm{C} 658=\mathrm{t}$ & & 5 & 0.001455604 & 0.2 \\
\hline 21 & $\mathrm{C} 101=\mathrm{t}$ & & 15 & $\mathrm{C} 153=\mathrm{t}$ & $\mathrm{C} 302=\mathrm{t}$ & 5 & 0.001455604 & 0.33 \\
\hline 22 & $\mathrm{C} 153=\mathrm{t}$ & $\mathrm{C} 302=\mathrm{t}$ & 14 & $\mathrm{C} 101=\mathrm{t}$ & & 5 & 0.001455604 & 0.36 \\
\hline 23 & $\mathrm{C} 101=\mathrm{t}$ & $\mathrm{C} 302=\mathrm{t}$ & 6 & $\mathrm{C} 153=\mathrm{t}$ & & 5 & 0.001455604 & 0.83 \\
\hline 24 & $\mathrm{C} 101=\mathrm{t}$ & $\mathrm{C} 153=\mathrm{t}$ & 6 & $\mathrm{C} 302=\mathrm{t}$ & & 5 & 0.001455604 & 0.83 \\
\hline 25 & $\mathrm{C} 650=\mathrm{t}$ & $\mathrm{C} 657=\mathrm{t}$ & 25 & $\mathrm{C} 336=\mathrm{t}$ & & 4 & 0.001164483 & 0.16 \\
\hline 26 & $\mathrm{C} 336=\mathrm{t}$ & $\mathrm{C} 657=\mathrm{t}$ & 20 & $\mathrm{C} 650=\mathrm{t}$ & & 4 & 0.001164483 & 0.2 \\
\hline 27 & $\mathrm{C} 332=\mathrm{t}$ & $\mathrm{C} 657=\mathrm{t}$ & 13 & $\mathrm{C} 658=\mathrm{t}$ & & 4 & 0.001164483 & 0.31 \\
\hline 28 & $\mathrm{C} 330=\mathrm{t}$ & $\mathrm{C} 650=\mathrm{t}$ & 12 & $\mathrm{C} 338=\mathrm{t}$ & & 4 & 0.001164483 & 0.33 \\
\hline 29 & $\mathrm{C} 336=\mathrm{t}$ & $\mathrm{C} 650=\mathrm{t}$ & 11 & $\mathrm{C} 657=\mathrm{t}$ & & 4 & 0.001164483 & 0.36 \\
\hline 30 & $\mathrm{C} 338=\mathrm{t}$ & $\mathrm{C} 650=\mathrm{t}$ & 8 & $\mathrm{C} 330=\mathrm{t}$ & & 4 & 0.001164483 & 0.5 \\
\hline 31 & $\mathrm{C} 330=\mathrm{t}$ & $\mathrm{C} 338=\mathrm{t}$ & 8 & $\mathrm{C} 650=\mathrm{t}$ & & 4 & 0.001164483 & 0.5 \\
\hline 32 & $\mathrm{C} 303=\mathrm{t}$ & & 30 & $\mathrm{C} 001=\mathrm{t}$ & & 3 & 0.000873362 & 0.1 \\
\hline 33 & $\mathrm{C} 336=\mathrm{t}$ & $\mathrm{C} 657=\mathrm{t}$ & 20 & $\mathrm{C} 658=\mathrm{t}$ & & 3 & 0.000873362 & 0.15 \\
\hline 34 & $\mathrm{C} 153=\mathrm{t}$ & $\mathrm{C} 302=\mathrm{t}$ & 14 & $\mathrm{C} 001=\mathrm{t}$ & & 3 & 0.000873362 & 0.21 \\
\hline 35 & $\mathrm{C} 808=\mathrm{t}$ & & 12 & $\mathrm{C} 650=\mathrm{t}$ & & 3 & 0.000873362 & 0.25 \\
\hline 36 & $\mathrm{C} 005=\mathrm{t}$ & $\mathrm{C} 658=\mathrm{t}$ & 12 & $\mathrm{C} 650=\mathrm{t}$ & & 3 & 0.000873362 & 0.25 \\
\hline 37 & $\mathrm{C} 001=\mathrm{t}$ & $\mathrm{C} 302=\mathrm{t}$ & 10 & $\mathrm{C} 153=\mathrm{t}$ & & 3 & 0.000873362 & 0.3 \\
\hline 38 & $\mathrm{C} 519=\mathrm{t}$ & & 9 & $\mathrm{C} 005=\mathrm{t}$ & & 3 & 0.000873362 & 0.33 \\
\hline 39 & $\mathrm{C} 336=\mathrm{t}$ & $\mathrm{C} 658=\mathrm{t}$ & 9 & $\mathrm{C} 657=\mathrm{t}$ & & 3 & 0.000873362 & 0.33 \\
\hline 40 & $\mathrm{C} 005=\mathrm{t}$ & $\mathrm{C} 650=\mathrm{t}$ & 8 & $\mathrm{C} 658=\mathrm{t}$ & & 3 & 0.000873362 & 0.5 \\
\hline 41 & $\mathrm{C} 301=\mathrm{t}$ & & 8 & $\mathrm{C} 302=\mathrm{t}$ & & 3 & 0.000873362 & 0.38 \\
\hline 42 & $\mathrm{C} 001=\mathrm{t}$ & $\mathrm{C} 153=\mathrm{t}$ & 3 & $\mathrm{C} 302=\mathrm{t}$ & & 3 & 0.000873362 & 1 \\
\hline
\end{tabular}

Sumber: Data penelitian 2017 